\title{
Spermatozoon as a Vehicle for Viruses
}

\author{
Elizaveta E Bragina ${ }^{1 *}$, Bocharova $\mathrm{EN}^{2}$ and Azova $\mathrm{MM}^{3}$ \\ ${ }^{1}$ Department of Electron microscopy, MV Lomonosov Moscow State University, Russia \\ ${ }^{2}$ Moscow Scientific and Practical Center of Dermatology, Russia \\ ${ }^{3}$ Medical Institute of RUDN University, Russia
}

Submission: April 04, 2017; Published: June, 30, 2017

*Corresponding author: Elizaveta E Bragina, Department of Electron microscopy, AN Belozersky Research Institute of Physico-Chemical Biology Moscow State University, 119992, Moscow, Leninskye gory, house 1, building 40, Moscow, Russia, Email: bragor@genebee.msu.ru

Abstract

In the last decade, a viral infection of semen and sperm is the subject of intensive research. The research of viral infection of spermatozoa and its consequences for reproduction reached its peak with the beginning and development of methods of artificial reproduction. There are number of viruses known that they can infect the semen-the human immunodeficiency virus (HIV), human papilloma virus (HPV), hepatitis B virus (HBV), hepatitis C virus (HCV), and herpes simplex virus (HSV). Intra-gamete viral infection of spermatozoa is a widespread phenomenon. It is not yet enough data that would determine the true role of vertical virus transmission for the infection spread, and for abnormalities at embryonic development. However, there are more data available that can prove these phenomena. Solution to the problem of the possibility of a viral infection in human sperm is of fundamental importance. If the germ cells are infected themselves, then the mechanisms of reproduction may be involved. In this case, specific antiviral therapy for men can prevent some cases of miscarriage at a natural pregnancy and improve the outcomes of ART applications.

\section{Introduction}

In the last decade, a viral infection of semen and sperm is the subject of intensive research. The research of viral infection of spermatozoa and its consequences for reproduction reached its peak with the beginning and development of methods of artificial reproduction. There are number of viruses known that they can infect the semen-the human immunodeficiency virus (HIV), human papilloma virus (HPV), hepatitis B virus (HBV), hepatitis $\mathrm{C}$ virus (HCV), and herpes simplex virus(HSV). The questions arises from these finding is whether the viral infection stays in semen fluid only or there is a possibility that viruses can be directly transported with human spermatozoa, and whether sperm infected with viruses is capable of transferring it into the egg during fertilization, that is true through vertical transmission.

\section{HIV}

Semen washing is a safer reproductive strategy that HIVdiscordant couples in which the male is infected can use to achieve pregnancy [1]. Although the presence of HIV in spermatozoa has been a matter of debate, HIV DNA was detected in $69.2 \%$ of purified sperm from HIV-positive men [2]. The positive rate after sperm washing was estimated as $6 \%$. According to the authors this high positive rate could be due to contamination
[3]. Nevertheless, there is evidence of intra-gamete localization of HIV. Dussaix et al. [4] localized HIV particles in infected spermatozoa with the transmission electron Microscopy (TEM) and demonstrated, with PCR analysis, that infected sperm was able to transmit the virus to blood leukocytes . Piomboni, Baccetti [5] published images taken with an electron microscope, showing HIV-1 in spermatozoa infected in vitro or obtained from AIDS patients, and improved the results by immunogold labeling with anti-HIV-1 antibodies. Muciaccia et al. [6] using molecular biology techniques determined that HIV-infected patients are capable of producing a small number of HIV-infected sperm.

To prove the possibility of vertical transmission of HIV in human spermatozoa, Wang et al. [7] made a plasmid construction with a transfection, and made heterologous fertilization of a zona-free hamster oocytes by human spermatozoon, the oocytes was examined by fluorescence in situ hybridization (FISH), RTPCR, and Immunofluorescence assay (IFA). The FISH signals for HIV-1 gag DNA were observed in the nuclei and chromosomes of transfected human sperm, male pronuclei of zygotes, and nuclei of blastomeres in the two-cell embryos, indicating that the HIV1 gag gene could be integrated into the sperm genome. Using RT-PCR, the positive bands for the target gene were observed in the transfected human sperm and two-cell embryos. These 
results further confirm that the target gene can be transcribed into mRNA in human sperm and embryonic cells. Positive signals for the HIV-1 p24 gag protein were shown by IFA in two-cell embryos containing the sperm-mediated target gene and not in the transfected human sperm, which indicates that the spermmediated target gene is being translated into HIV-1 p24 gag protein in embryonic cells, but not in sperm cells with compact metabolically inert chromatin. So, evidence showed that HIV1 nucleic acid was present in the spermatozoa of HIV/AIDS patients, that HIV-1 provirus is present on the patient sperm chromosome, that the integrated provirus could be transferred into early embryo by fertilization, and that it could replicate alongside the embryonic genome and subsequently express its protein in the embryo. These findings indicate the possibility of vertical transmission of HIV-1 from the sperm genome to the embryonic genome by fertilization. Wang et al. [7] showed the presence of HIV1 in spermatozoa of 9 out of 33 (27.2\%) patients, viral load is small $1.3 \%$.Though semen washing appears to significantly reduce the risk of transmission in HIV-discordant couples desiring children, this probability is present.

\section{HBV}

Hadchouel et al. [8] studied the presence and state of HBV DNA in sperm samples obtained from 17 patients with an HBV infection. Restriction analysis of cellular DNA revealed the presence of integrated sequences of HBV DNA in the sperm of some patients. Huang et al. [9] had also demonstrated that HBV could integrate into human sperm chromosomes. Integrations of viral DNA into sperm chromosomes which are multisite and non specific can increase the instability of sperm chromosomes. The results have suggested the possibility of vertical transmission of HBV via the germ line to the next generation.

Ali et al. [10] demonstrated the correctness of this hypothesis. They identified the gene expression of hepatitis B (HB S and C genes) in early embryonic cells after the introduction of motile sperm carrying HBV DNA in zona-free hamster oocytes, using IVF. The authors showed that sperm-mediated HBV genes are able to replicate and express in cells of the early embryo. Ahmed et al. [11] constructed the plasmid pIRES2-EGFP-HBs which expressed an enhanced green fluorescent protein as a reporter for the expression of the hepatitis B virus $\mathrm{S}$ gene. After exposure to the plasmid, human spermatozoa were used to fertilize the zona-free hamster oocytes. The results showed that HBs DNA positive bands were detected in the embryos with green fluorescence (PCR and RT-PCR).

Wang et al. [12] investigated eight male HBV carriers whose wives were negative for any HBV marker and their eight aborted fetuses who had been infected with HBV in utero. The homologies of HBV sequences between father and fetus were very high. Six father/fetus pairs had the same subtype adw. The sequences of the fragment were identical between father and fetus in 4 cases, and eleven common point mutations between father and fetus were found. On the other hand, Cai and Zhu
[13] observed 164 pairs in which the man was the carrier of the hepatitis B virus (only for serological markers). None of the newborns was infected. It can be assumed that when fertilization with an infected spermatozoon, the fetus is eliminated and if not-infected spermatozoon participates in fertilization, healthy children are born.

\section{$\mathrm{HCV}$}

Data on the presence of hepatitis C virus in spermatozoa is controversial, but some authors were able to demonstrate HCV in spermatozoa after a wash and swim-up procedure. In the washed motile sperm, HCV RNA was determined by nested, but not a single-cycle PCR [14]. Ma et al. [15] have constructed the recombinant plasmid pIRES2-EGFP-HCV C. The HCV C gene was able to pass through the sperm membrane and integrate into the sperm genome. Human sperm carrying the HCV C gene was able to achieve normal fertilization. The replication of the sperm-mediated HCV C gene was synchronized with that of the host genome. Sperm samples from 20 patients in the healthy control group and 16 in the HCV infection group were used for interspecies in vitro fertilization of zona-free golden hamster ova. The are frequency of spermatozoan aberrations was studies on sperm metaphase spreads, and it was significantly higher in the HCV infection group compared with healthy group [16]. These results provide evidence for vertical transmission of the HCV C gene from father-to-child via human sperm.

\section{HPV}

Integration of HPV DNA in sperm DNA was shown for strains of oncogenic risk, the presence of HPV DNA was detected in the sperm of about $15 \%$ of infertile patients [17]. Infertile patients had a higher HPV DNA prevalence in sperm cells than the other groups [18]. The prevalence of HPV semen infection found in all groups was as follows: patients with genital warts, $53.8 \%$, infected partners $40.9 \%$, infertile patients, $10.2 \%$, fertile controls, $2.2 \%$. This study demonstrated a very high prevalence of infection in the semen of patients with risk factors for HPV. In situ hybridization revealed a clear HPV localization at the equatorial region of sperm head in infected samples, suggesting that these sites may mediate HPV binding and the interaction of the spermatozoon with the oocyte [19]. Sperm transfected with HPV E6/E7 genes and sperm exposed to HPV L1 capsid protein are capable to penetrate the oocyte and transfer the virus into oocytes, in which viral genes are then activated and transcribed. These data show that sperm might function as vectors for HPV transfer into the oocytes [20]. The prevalence of HPV on sperm in 155 testicular cancer patients, after orchiectomy and after 12 months from surgery or from the end of adjuvant treatments was analyzed. All patients showed a significantly higher prevalence of semen infection than controls ( $9.5 \%$ and $2.4 \%$ respectively). The use of infected spermatozoa for ART can be a risk factor. Garolla et al. [21] demonstrated that 54 male partner of 226 infertile couples had HPV semen infection confined to sperm, confined to exfoliated cells, or in both cells. A reduction in 
natural and assisted cumulative pregnancy rate and an increase in miscarriage rate are related to the presence of HPV at the spermatozoa level.

\section{HSV}

The presence of herpesvirus in urogenital tract of randomly selected male patients without a history of genital herpes was for the first time shown by Centifanto et al. [22]. The possible role of sperm in herpesvirus transmission was investigated by Deture et al. [23] using the tissue culture method. The authors revealed Herpes virus infectivity in the semen of 2 out of 30 healthy male subjects with recurrent infections with herpes obtained when subjects were free of lesions. Later, HSV was isolated using cell cultures from the ejaculate of $40 \%$ of patients with fertility disorders [24]. Transmission of genital herpes by donor insemination was reported by Moore et al. [25]. The donor was an asymptomatically carrier of a primary herpes simplex virus type 2 (HSV-2) infection from his constant sexual partner. His fresh semen was used to inseminate HSV-sero negative recipient; in one, a primary HSV-2 infection developed. Direct evidence of transmission from donor to recipient was documented by restriction enzyme analysis of the HSV-2 isolates obtained from the donor's semen and from the recipient's cervix.

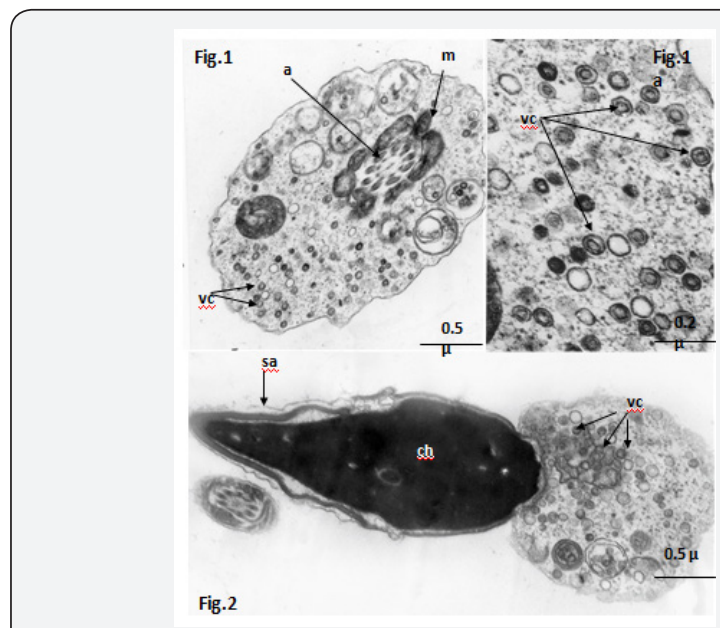

Figure 1, 1a (fragment). TEM, transverse section through the middle part of the spermatozoon flagellum. vc- HSV capsids, a tail axonema, $\mathrm{M}$ - mitochondria. (29)

Figure 2. TEM. Longitudinal section of normal sperm. sa - sperm acrosome, ch - chromatin, vc - HSV capsids (29).

HSV DNA has been detected in human spermatozoa. Kapranos et al. [26] revealed HSV DNA in the sperm of infertile men by the polymerase chain reaction (PCR), but did not reveal it in the control group. Kulcsar et al. [27] identified HSV antigens in spermatozoa of patients with different diseases by the immunofluorescence method (IFM), Kotronias, Kapranos [28] demonstrated the presence of HSV DNA by in situ hybridization (ISH). We observed the HSV capsids in the nucleus and very often in residual cytoplasm of the spermatozoa of male partner from infertile wedded pairs [29]. We could see HSV procapsids, type B capsids and type C capsids with partial encapsidation (nucleacapsids), although no mature virions were detected in spermatozoa (Figure $1 \& 2$ ). These structures are indeed HSV, we proved this by immunofluorescence (IF) using the antibodies to HSV1 and HSV2 (Figure 3) and in situ hybridization (ISH) with biotinylated probes for HSV (Figure 4). HSV DNA and antigen was detected not only in the spermatozoa of native semen, but in the isolated fraction of motile spermatozoa [30,31]. The preservation of the HSV genome in the motile morphologically normal sperm is an argument in favor of the vehiculation of the herpes virus by spermatozoa to the offspring during natural insemination or the use of various assisted reproductive techniques including IVF/ICSI.

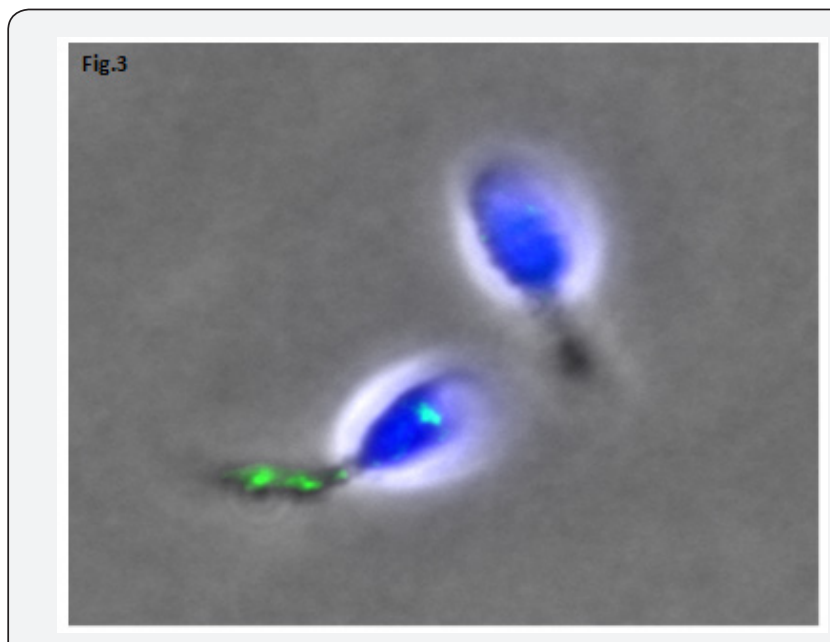

Figure 3: IF. Infected (left) and uninfected (wright) sperm. IF. HSV antigen (green) and DAPI stain for DNA (blue) (30).

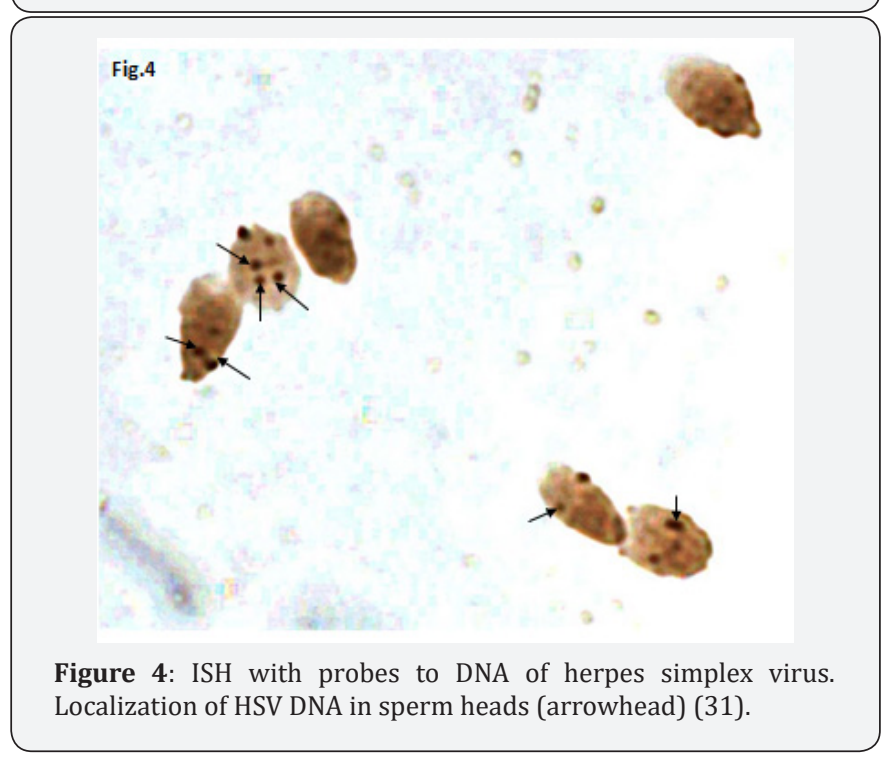

Why is the process of HSV maturation in spermatozoa incomplete? When somatic cells with wild-type herpes simplex virus are infected with HSV, the virus's capsid is assembled in the nucleus of the infected cell from the proteins synthesized in the cytoplasm. The cause of incomplete viral infection, i.e., arrest of the virus formation at the stage of formation of incomplete 
particles may be disordered transportation of viral proteins. A strain of HSV UL26 mutation of the gene, that encodes the protease protein nucleocaspid frame, was obtained. This protease ensures transportation of the capsid's proteins from the cytoplasm to the nucleus. Cultivation of this strain causes abortive infection with the accumulation of capsids in the cytoplasm [32]. This is morphologically identical to what we observe in the spermatozoa.

The maturation of sperm is a complex process that includes the condensation of chromatin, nearly complete disappearance of nuclear pores, cessation of nuclear-cytoplasmatic transport [33]. We suggested that cessation of nuclear-cytoplasmatic transport during spermiogenesis created impermissible conditions for development of the productive HSV infection, leading to formation of incomplete viruses. This phenomenon, morphologically expressing in the presence of HSV capsid in the cytoplasmic droplet of spermatozoa, leads to the preservation of the viral genome in the spermatozoon's nucleus. The evidence of DNA HSV preservation in spermatozoa is the positive result of ISH with HSV DNA probes. HSV is a nuclear virus, it cannot penetrate very dense chromatin of mature sperm, so mature sperm cells are insensitive to HSV infection. This was confirmed by Pallier et al. [34] experiments. The authors incubated ejaculated sperms with herpes simplex virus type 2 (HSV2). They showed that a few viral particles HSV2 adhered to the sperm membrane in the presence of seminal fluid, but viruses couldn`t be found inside sperm. We assumed that sperm infection occurs in the stage of immature germ cells. In experimental animals, we demonstrated the immature sperm cells are susceptible to herpes simplex virus [35] (Figure 5). The sperm from male partner of group with high level of spontaneous abortion or failure of in vitro fertilization were infected with HSV capsides more frequently than the control groups- $68 \%$ versus $9 \%(p=0.003)$ [36]. It can be assumed that HSV is inactive in mature spermatozoa, since the viral genome is localized in the highly condensed sperm chromatin. After fertilization the male pronucleus exposed decondensation, sperm and viral gene expressions activate. This mechanism of intragamete viral genome activation after fertilization is proved for HIV and HBV $[7,10,11]$. To assess the degree of an euploidy in spermatozoa from samples with HSV infected sperm, the fluorescence in situ hybridization (FISH) with DNA probes specific for chromosomes $1, \mathrm{X}$, and $\mathrm{Y}$ was used. FISH analysis demonstrated no difference in the frequency of the non disjunction of chromosomes $1, \mathrm{X}$, and $\mathrm{Y}$ between infertile patients with HSV-infected sperm and fertile sperm donors [36]. A partial spermatogenic arrest at the early stages of meiotic prophase I in the semen of patients with HSV infected sperm was demonstrated [37]. A noticeable cytopathic effect and the change in the number of immature germ cells due to the presence of the herpetic infection, suggests that the effect of HSV on spermatogenesis takes place at the cells of spermatogenic epithelium.

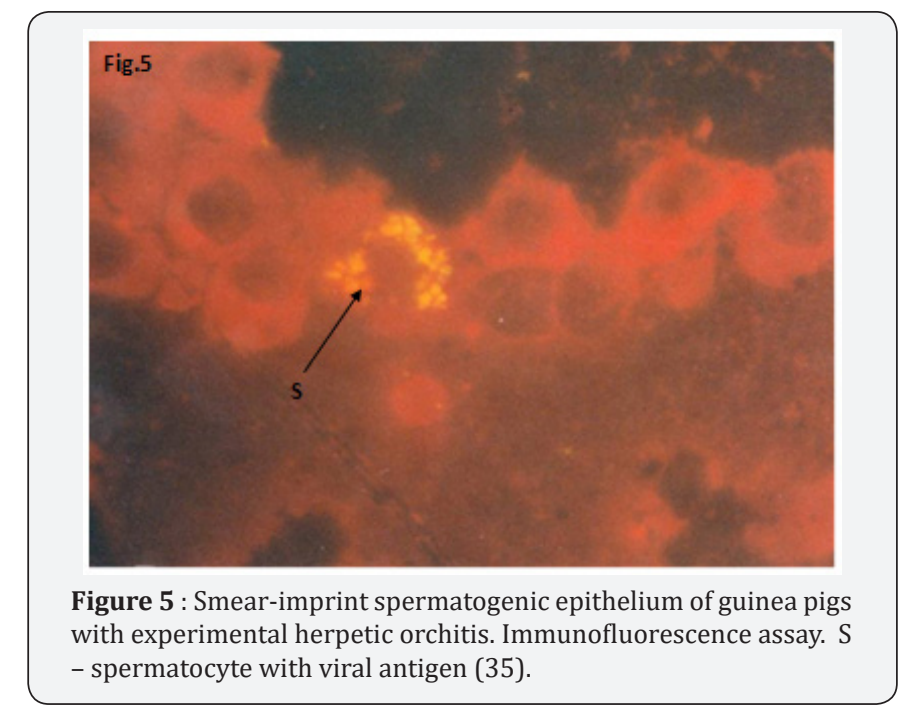

\section{ZIKA Virus}

Mansuy et al. [38] found persistence of Zika virus after symptomatics infections were scarce and even non existent for asymptomatic ones. In mice infected with the Zika virus, it remained in the testicles for a long time. The testicular atrophy was observed [39].

\section{Conclusion}

Intra-gamete viral infection of spermatozoa is a widespread phenomenon. It is not yet enough data that would determine the true role of vertical virus transmission for the infection spread, and for abnormalities at embryonic development. However, we can state that there are more and more data available that can prove both phenomenon, at least we cannot ignore them. Solution to the problem of the possibility of a viral infection in human sperm is of fundamental importance. If the germ cells are infected themselves, then the mechanisms of reproduction may be involved. In this case, specific antiviral therapy for men can prevent some cases of miscarriage at a natural pregnancy and improve the outcomes of art applications.

\section{Acknowledgement}

This work was supported by Moscow State University Development Program PNR5.13 and by the Ministry of Education and Science of the Russian Federation (the Agreement number 02.A03.21.0008).

\section{References}

1. Semprini AE, Macaluso M, Hollander L, Vucetich A, Duerr A, et al. (2013) Safe conception for HIV-discordant couples: Insemination with processed semen from the HIV-infected partner. American Journal of Obstetrics and Gynecology 208(5): 402.

2. Cardona-Maya W, Velilla P, Montoya CJ, Cadavid A, Rugeles MT (2009) Presence of HIV-1 DNA in spermatozoa from HIV-positive patients: changes in the semen parameters. Curr HIV Res 7(4): 418-424.

3. Savasi V, Ferrazzi E, Lanzani C, Oneta M, Parrilla B, et al. (2007) Safety of sperm washing and ART outcome in 741 HIV-1-serodiscordant 
couples. Hum Reprod 22(3): 772-777.

4. Dussaix E, Guetard D, Dauguet C (1993) Spermatozoa as potential carriers of HIV. Res Virol 144(6): 437-445.

5. Piomboni P, Baccetti B (2000) Spermatozoon as a vehicle for HIV-1 and other viruses: a review. Mol Reprod Dev 56(2 Suppl): 238-242.

6. Muciaccia B, Corallini S, Vicini E, Padula F, Gandini L, et al. (2007) HIV-1 viral DNA is present in ejaculated abnormal spermatozoa of seropositive subjects. Hum Repr 22(11): 2868-2878.

7. Wang D, Li LB, Hou ZW, Kang XJ, Xie QD, et al. (2011) The integrated HIV-1 provirus in patient sperm chromosome and its transfer into the early embryo by fertilization. PLoS One 6(12): e28586.

8. Hadchouel M, Scotto J, Huret JL, Molinie C, Villa E, et al. (1985) Presence of HBV DNA in spermatozoa: a possible vertical transmission of HBV via the germ line. J Med Virol 16(1): 61-66.

9. Huang JM, Huang TH, Qiu HY, Fang XW, Zhuang TG, et al. (2003) Effects of hepatitis B virus infection on human sperm chromosomes. World J Gastroenterol 9(4): 736-740.

10. Ali BA, Huang TH, Xie QD (2005) Detection and expression of hepatitis $B$ virus $X$ gene in one and two-cell embryos from golden hamster oocytes in vitro fertilized with human spermatozoa carrying HBV DNA Mol Reprod Dev 70(1): 30-36.

11. Ahmed MM, Huang TH, Xie QD (2008) A sensitive and rapid assay for investigating vertical transmission of hepatitis B virus via male germ line using EGFP Vector as reporter. J Biomed Biotechnol 2008: 495436.

12. Wang S, Peng G, Li M, Xiao H, Jiang P, et al. (2003) Identification of hepatitis $B$ virus vertical transmission from father to fetus by direct sequencing. Southeast Asian J Trop Med Public Health 34(1): 106-113.

13. Cai QX, Zhu YY (2013) Is hepatitis B virus transmitted via the male germ line? A seroepidemiological study in fetuses. Int J Infect Dis 17(1): e54-e58.

14. Meseguer M, Garrido N, Gimeno C, Remohí J, Simón C, et al. (2002) Comparison of polymerase chain reaction-dependent methods for determining the presence of human immunodeficiency virus and hepatitis C virus in washed sperm. Fertil Steril 78(6): 1199-1202.

15. Ma M, Zhu Y, Wang D, Hou Z, Huang J, et al. (2016) Research on the Vertical Transmission of Hepatitis C Gene from Father-to-child via Human Sperm. Clin Lab 62(1-2): 1-6.

16. Zhu Y, Ma M, Huang J, Hou Z, Wang D, et al. (2016) Effects of Hepatitis C Virus Infection on Human Sperm Chromosomes. Clin Lab 62 (3): 373 379

17. Rintala MA, Grenman SE, Pollanen PP, Suominen JJ, Syrjanen SM (2004) Detection of high-risk HPV in semen and its association with quality of semen. Int J STD AIDS 15(11): 740-743.

18. Foresta C, Pizzol D, Moretti A, Barzon L, Palù G, et al. (2010) Clinical and prognostic significance of human papillomavirus DNA in the sperm or exfoliated cells of infertile patients and subjects with risk factors. Fertil Steril 94(5): 1723-1727.

19. Schillaci R, Capra G, Bellavia C, Ruvolo G, Scazzone C, et al. (2013) Detection of oncogenic human papillomavirus genotypes on spermatozoa from male partners of infertile couples. Fertil Steril 100(5): 1236-1240.

20. Foresta C, Ferlin A, Bertoldo A, Patassini C, Zuccarello D, et al. (2011) Human papilloma virus in the sperm cryobank-an emerging problem? Int J Androl 34(3): 242-246.

21. Garolla A, Engl B, Pizzol D, Ghezzi M, Bertoldo A, et al. (2016) Spontaneous fertility and in vitro fertilization outcome: new evidence of human papillomavirus sperm infection. Fertil Steril 105(1): 65-72.
22. Centifanto YM, Drylie DM, Deardourff SL, Kaufman HE (1972) Herpesvirus type 2 in the male genitourinary tract. Science 178 (4058): 318-319.

23. Deture FA, Drylie DM, Kaufman HE, Centifanto YM (1978) Herpesvirus type 2: study of semen in male subjects with recurrent infections. J Urol 120 (4): 449-451.

24. Csata S, Kulcsar G (1991) Virus-host studies in human seminal and mouse testicular cells. Acta Chir Hung 32(1): 83-90.

25. Moore DE, Ashley RL, Zarutskie PW, Coombs RW, Soules MR, et al. (1989) Transmission of genital herpes by donor insemination. JAMA 261(203): 3441-3443.

26. Kapranos N, Petrakou E, Anastasiadou C, Kotronias D (2003) Detection of herpes simplex virus, cytomegalovirus, and Epstein-Barr virus in the semen of men attending an infertility clinic. Fertil Steril 79(Suppl. 3): 1566-1570.

27. Kulcsar G, Csata S, Nasz I (1991) Investigations into virus carriership in human semen and mouse testicular cells. Acta Microbiol Hungar 38(2): 127-132.

28. Kotronias D, Kapranos N (1998) Detection of herpes simplex virus DNA in human spermatozoa by in situ hybridization technique. In Vivo 12(4): 391-394.

29. Bragina EE, Abdumalikov RA, Bocharova EN, Kusch AA, Gribencha SV, et al. (2000) Intragamete herpes infection in the human sperm. Androl Genit Surgery 3: 81-82.

30. Bocharova EN, Abdumalikov RA, Bragina EE, Klimova RR, Adueva SM, et al. (2003) Determination of the proteins and capsids of herpes simplex virus in human spermatozoa. Dokl Biol Sci 391: 379-383.

31. Bocharova EN, Zavalishina LE, Bragina EE, Klimova RR, Gusak YK, et al. (2007) Detection of herpes simplex virus genomic DNA in spermatozoa of patients with fertility disorders by in situ hybridization. Dokl Biol Sci 412: 82-86.

32. Church GA, Wilson DW (1997) Study of herpes simplex virus maturation during a synchronous wave of assembly. J Virol 71(5): 3603-3612.

33. De Kretser DM, Kerr J (1988) The cytology of the testis. In: Knobil E, Neill J (Eds.), The physiology of reproduction. Raven Press, Ltd. New York, USA, pp. 837-932.

34. Pallier C, Tebourbi L, Chopineau-Proust S, Schoevaert D, Nordmann P, et al. (2002) Herpesvirus, cytomegalovirus, human sperm and assisted fertilization. Hum Reprod 17(5): 1281-1287.

35. Gribencha SV, Bragina EE, Abdumalikov RA, Bocharova EN, Kurilo LF (2007) Detection of type 2 herpes simplex virus in cells of spermatogenic epithelium in infected testes of guinea pigs. Bull Exp Biol Med 144(1): 73-76.

36. Bocharova EN, Bragina EE, Gusak IuK, Zotov VV, Tereshchenko AB, et al. (2007) Herpetic infection of spermatozoa in failure of reproductive technologies and spontaneous abortion. Urologiia 3: 59-63.

37. Bocharova EN, Kurilo LF, Shilě̌ko LV, Bragina EE, Iurov IuB, et al. (2008) Analysis of germ cell populations in ejaculate of men infected with herpes simplex virus. Ontogenez 39(1): 47-57.

38. Mansuy JM, Suberbielle E, Chapuy-Regaud S, Mengelle C, Bujan L, et al. (2016) Zika virus in semen and spermatozoa. Lancet Infect Dis. 16(10): 1106-1107.

39. Uraki R, Hwang J, Jurado KA, Householder S, Yockey LJ, et al. (2017) Zika virus causes testicular atrophy. Sci Adv 3(2): e1602899. 
This work is licensed under Creative Commons Attribution 4.0 Licens

DOI: 10.19080/IJCSMB.2017.02.555593
Your next submission with Juniper Publishers will reach you the below assets

- Quality Editorial service

- Swift Peer Review

- Reprints availability

- E-prints Service

- Manuscript Podcast for convenient understanding

- Global attainment for your research

- Manuscript accessibility in different formats (Pdf, E-pub, Full Text, Audio)

- Unceasing customer service

Track the below URL for one-step submission https://juniperpublishers.com/online-submission.php 